\title{
Effect of Different Treatments on Antioxidative Stability of the Scallop Protein Hydrolysates
}

\author{
Na Lin ${ }^{1,2}$, Ang Hu1,2, Zhidong Liu1,2* \\ ${ }^{1}$ East China Sea Fisheries Research Institute, Chinese Academy of Fishery Sciences, Shanghai, China \\ ${ }^{2}$ Key Laboratory of Oceanic and Polar Fisheries, Ministry of Agriculture, Shanghai, China \\ Email: ${ }^{\star z d}$-liu@hotmail.com
}

How to cite this paper: Lin, N., Hu, A. and Liu, Z.D. (2020) Effect of Different Treatments on Antioxidative Stability of the Scallop Protein Hydrolysates. Food and Nutrition Sciences, 11, 603-614. https://doi.org/10.4236/fns.2020.117043

Received: May 24, 2020

Accepted: July 6, 2020

Published: July 9, 2020

Copyright (c) 2020 by author(s) and Scientific Research Publishing Inc. This work is licensed under the Creative Commons Attribution International License (CC BY 4.0).

http://creativecommons.org/licenses/by/4.0/ (c) (i) Open Access

\begin{abstract}
Effects of different treatments on the antioxidant activity of scallop protein hydrolysates (SPH) were evaluated using DPPH radical scavenging activity and reducing power. Results showed that the antioxidant activity of SPH had good heating-resistance from $25^{\circ} \mathrm{C}$ to $65^{\circ} \mathrm{C}$. The antioxidant activity of $\mathrm{SPH}$ could retain under acidic environment, but rapidly reduced under alkaline conditions. Addition of D-galactose, D-xylose, and D-fructose at $65^{\circ} \mathrm{C}$ could increase the antioxidant activity of SPH, but no such effect was not observed at this temperature. With the increase of storage time, the antioxidant activity of SPH gradually decreased. Moreover, pepsin digestion treatment slightly reduced the antioxidant activity of $\mathrm{SPH}$, and further trypsin and mixed enzyme (trypsin + chymotrypsin) digestion significantly reduced this activity ( $\mathrm{p}$ $<0.05)$. In conclusion, SPH may be used as food ingredients or food supplements in different food fields.
\end{abstract}

\section{Keywords}

Argopecten irradias, Protein Hydrolysates, Antioxidant Activity, Stability, Treatment

\section{Introduction}

Scallop (Argopecten irradias) is a nutritious, deliciously edible shellfish. Scallop production in China has increased to 2 million tons in 2018 (FAO, 2018) and the processing is increasing with the continuous expansion of scallop farming. The adductor muscle of scallop is the main edible part, and the other parts are usually seemed as by-products of scallop processing and discarded as wastes. These by-products of scallop processing lead to the waste of resources and environmental pollution problems [1]. 
The hydrolysates of proteins have received much attention in recent years because of their diverse bioactivities including antioxidative, immunomodulatory, anti-obesity, hypocholesterolemic, anticancer, antidiabetic, antimicrobial and antihypertensive activities. The protein hydrolysates can serve as a potential additive in various food formulations due to their high nutrition, easy digestibility, and low allergenicity. The potential applications of protein hydrolysates or peptides as food additives have been highlighted by many researchers [2]. However, the characteristics of these protein hydrolysates have also posed several challenges for their applications in food formulations. These important challenges include the reaction with other food components, limited stability and lost bioactivities, etc.

Antioxidant activity is one of the most important and fundamental functions in life systems. Many studies have illustrated that oxidative injuries are closely associated with many human diseases, such as cardiovascular diseases, cancer and neurological disorders [3]. Although various antioxidants from protein sources have been identified, these researches had mainly focused on the purification, antioxidant activities (free radical scavenging activity, reducing power, metal chelating ability and lipid peroxidation inhabitation activity, etc.) assessment and structural analysis of these antioxidants, especially the single and pure peptides [4]. With increasing consumers' food safety consciousness, natural antioxidants have potential health-promoting effects compared to synthetic antioxidants; thus they have received much more attention than the latter [5].

As we all know, during processing, storage, utilization and gastrointestinal digestion, protein hydrolysates are usually encountered different environment stress, such as, thermal treatment, $\mathrm{pH}$ modification, interactions with other components in food matrix and gastrointestinal tract, etc. Hence, the research on the stability of the protein hydrolysates against the above-mentioned treatments has become critical. However, more researches focused on the stability of the single, pure peptides other than the hydrolysates of proteins [5] [6]. In fact, more and more hydrolysates of proteins rather than the single, pure peptide are applied as food ingredients, food additives. For example, porcine bone protein hydrolysate and skipjack roe protein hydrolysate can be used as emulsifying agent [7]. Meanwhile, the low stability of these protein hydrolysates has limited their use. The antioxidant stability of food protein hydrolysates is still opaque; even some results are contradictory. More research needs to be done about the antioxidant stability of protein hydrolysates.

The objective of this study was to investigate the effects of food processing, storage conditions, and simulated gastrointestinal digestion on the antioxidant stability of SPH as food ingredients or food additives.

\section{Materials and Methods}

\subsection{Materials}

Scallops (Argopecten irradias) were purchased from Oriental international aq- 
uatic products center (Shanghai, China) in November, 2017. Neutral protease (100,000 U/g) was purchased from Shanghai Yuanye Biological Technology Co., Ltd (Shanghai, China). Trypsin (50,000 U/g), pepsin (100,000 U/g), chymotryp$\sin (100,000 \mathrm{U} / \mathrm{g}), \mathrm{D}-(+)$-xylose, $\mathrm{D}-(-)$-fructose, $\mathrm{D}-(+)$ sucrose, and $\mathrm{D}-(+)$ galactose were obtained from Sigma-Aldrich (USA). Other reagents were analytical grade. Ultrafiltration centrifugal units (molecular weight cut-off (MWCO) of 3 $\mathrm{kDa}$ ) were purchased from Merck (Germany).

\subsection{Methods}

\subsubsection{Extraction of Scallop By-Products Protein}

According to the methods described by Marmon \& Undeland [8], the by-product of scallop processing and $95 \%$ ethanol were cooled at $4^{\circ} \mathrm{C}$ for at least $3 \mathrm{~h}$, respectively. The pre-cooled $95 \%$ ethanol was slowly added to raw materials with gentle stirring until the final substance/ethanol ratio reached $10 \%(\mathrm{w} / \mathrm{v})$. Then $\mathrm{pH}$ of the solution was adjusted to 7.0 and stored at $4^{\circ} \mathrm{C}$ overnight. Subsequently, the solution was centrifuged at $8000 \mathrm{r} / \mathrm{min}, 4^{\circ} \mathrm{C}$, for $10 \mathrm{~min}$, and the obtained precipitate was added to the pre-cooled $95 \%$ ethanol with gentle stirring until the final substance/ethanol ratio reached $10 \%(\mathrm{w} / \mathrm{v})$ and stored at $4^{\circ} \mathrm{C}$ overnight again. Then the solution was centrifuged at $8000 \mathrm{r} / \mathrm{min}, 4^{\circ} \mathrm{C}$, for $10 \mathrm{~min}$. The precipitate was collected and stored at $-20^{\circ} \mathrm{C}$ until further use.

\subsubsection{Preparation of $<3 \mathrm{kDa}$ of $\mathrm{SPH}$}

According to the methods described by Chai et al. [9], protein from the by-product of scallop processing (with $86 \%$ protein, $8 \%$ ash and $2 \%$ lipid) was incubated with neutral protease at an enzyme/substrate ratio of $1.5 \%(\mathrm{w} / \mathrm{w})$ protein concentration of $20 \%(\mathrm{w} / \mathrm{w}))$. The mixture was incubated at $\mathrm{pH} 7.0$ and $55^{\circ} \mathrm{C}$ for 4 h. The reaction was terminated by heating at $100^{\circ} \mathrm{C}$ for $10 \mathrm{~min}$ and cooled to room temperature. The hydrolysates were centrifuged at $10,000 \mathrm{r} / \mathrm{min}, 4^{\circ} \mathrm{C}$, for $20 \mathrm{~min}$ and the supernatant was collected. The supernatant was then fractionated by ultrafiltration membranes with $3 \mathrm{kDa} \mathrm{MWCO}$, producing molecular weight $>3 \mathrm{kDa}$ and $<3 \mathrm{kDa}$ fractions. The $<3 \mathrm{kDa}$ fraction of the hydrolysate was stored at $-20^{\circ} \mathrm{C}$ for further analysis.

\subsubsection{DPPH Radical Scavenging Activity}

DPPH radical scavenging activities of the samples were measured according to the method described by BLOIS [10] with minor modifications. One hundred microliters of $200 \mu \mathrm{M} \mathrm{DPPH}$ solution (dissolved in absolute ethanol) and the same volume of the samples were mixed and reacted at room temperature for 30 min keep in dark place. The absorbance was measured at $517 \mathrm{~nm}$ with a UV-spectrophotometer (TU1810, Beijing Purkinje General Instrument Co., Ltd. China). The blank solution contains DPPH solution and absolute ethanol, and BHT was used as a positive control. DPPH radical scavenging activity was calculated according to the following equation:

$$
\text { DPPH radical scavenging activity }(\%)=\left(A_{b}-A_{s}\right) / A_{b} \times 100
$$


where $A_{S}$ is the absorbance obtained from a sample and $A_{b}$ is the absorbance of the blank.

\subsubsection{Reducing Power}

Reducing power was measured according to the procedure described by Oyaizu [11] with minor modifications. Briefly, various concentrations of the sample solution $(1 \mathrm{~mL})$ were mixed with $1 \mathrm{~mL}$ of phosphate buffer $(0.2 \mathrm{M}, \mathrm{pH} 6.6)$ and 1.0 $\mathrm{mL}$ of potassium ferricyanide (1\%). After incubation at $50^{\circ} \mathrm{C}$ for $20 \mathrm{~min}, 1.0 \mathrm{~mL}$ of trichloroacetic acid (10\%) was added to the mixture. Then the mixed solution was centrifuged at $2000 \mathrm{~g}$ for $10 \mathrm{~min}$. The supernatant was collected and mixed with the deionized water and ferric chloride solution $(0.1 \%)$. After incubation at room temperature for $10 \mathrm{~min}$, the absorbance of the mixtures was measured at $700 \mathrm{~nm}$. BHT was used as a positive control.

\subsubsection{Stability of SPH}

\section{Effect of thermal treatment}

The sample solutions $(10 \mathrm{mg} / \mathrm{mL})$ were incubated at different treated temperatures $\left(25^{\circ} \mathrm{C}, 45^{\circ} \mathrm{C}, 65^{\circ} \mathrm{C}, 85^{\circ} \mathrm{C}\right.$ and $\left.100^{\circ} \mathrm{C}\right)$ in a temperature-controlled water bath for $1 \mathrm{~h}$, respectively. These samples were cooled to room temperature $\left(25^{\circ} \mathrm{C}\right)$. DPPH radical scavenging activity and reducing power of these samples were measured.

\section{Effect of $\mathrm{pH}$}

The sample solutions $(10 \mathrm{mg} / \mathrm{mL})$ were adjusted to different $\mathrm{pH}(3,5,7,9$ and 11), then vortexed for $10 \mathrm{~s}$ and incubated at $25^{\circ} \mathrm{C}$ for $1 \mathrm{~h}$ (Wong et al., 2019). Then $\mathrm{pH}$ of the sample solutions was adjusted to 7.0 with $1 \mathrm{M} \mathrm{HCl}$ (Hydrochloric acid) or $\mathrm{NaOH}$ (Sodium Hydroxide) solution. Distilled water was added until the final volume up to $20 \mathrm{~mL}$ of every solution. DPPH radical scavenging activity and reducing power of these samples were measured.

\section{Effect of storage time}

The samples were stored at $25^{\circ} \mathrm{C}$ for $0,3,7,14$, and $28 \mathrm{~d}$ and prepared the solutions $(10 \mathrm{mg} / \mathrm{mL})$, respectively [12]. DPPH radical scavenging activity and reducing power of these samples were measured.

\section{Effect of sugars}

The sample solutions $(10 \mathrm{mg} / \mathrm{mL})$ were prepared with the deionized water. Four types of sugars including D-(+)-xylose, D-(-)-fructose, D-(+) sucrose, and $\mathrm{D}-(+)$ galactose $(4 \mathrm{mg} / \mathrm{mL})$ were used in this study to represent the major components that occur in food system. Four sugars were added and incubated at $25^{\circ} \mathrm{C}$ and $65^{\circ} \mathrm{C}$ for $1 \mathrm{~h}$, respectively. DPPH radical scavenging activity and reducing power of these samples were measured.

\section{Effect of in-vitro gastrointestinal digestion}

An in-vitro system simulating gastrointestinal digestion was carried out according to the method of Zhu et al., [6]. The sample solutions were adjusted to pH 2.0 with $1 \mathrm{M} \mathrm{HCl}$. Pepsin was added to a level of $8 \%$ of SPH (w/w). The sample solutions was incubated at $37^{\circ} \mathrm{C}$ for $2 \mathrm{~h}$, terminated the reaction in boiling 
water for $10 \mathrm{~min}$. The solution was divided into two parts. One part was cooled to room temperature, centrifuged at $8000 \mathrm{rpm}$ for $10 \mathrm{~min}$ and the precipitate lyophilized. The other part was adjusted to $\mathrm{pH} 5.3$ with $1 \mathrm{M} \mathrm{NaOH}$ solution, and $\mathrm{pH} 7.5$ with $1.0 \mathrm{M} \mathrm{NaOH}$ solution, respectively. Trypsin or chymotrypsin or trypsin with chymotrypsin was added $(4 \%(\mathrm{w} / \mathrm{w})$ of SPH, and repeated the above steps, respectively. The supernatant was lyophilized, sealed in plastic bags and stored at $-20^{\circ} \mathrm{C}$ until use. DPPH radical scavenging activity and reducing power of these samples were assessed.

\subsubsection{Statistical Analysis}

All experiments were conducted in triplicates. Data were presented as mean \pm standard errors. Statistical analysis was performed by using SPSS 19.0 with one-way ANOVA. Comparison of means was carried out by using Fisher's Least Significant Difference (LSD) test. $\mathrm{p}<0.05$ was considered to have significant differences.

\section{Results}

Various researches have demonstrated that the hydrolysates of proteins usually have disadvantages of poor biological stability and affect their utilization. Most antioxidants from protein sources, due to proteins contain various antioxidant groups, act as free radicals scavengers, reducing agents, metal ion chelators, and lipid peroxidation inhibitors, etc. [4]. Some antioxidant from proteins are more effective as radical scavengers or lipid peroxidation inhibitors, while others have metal chelating ability or reducing power. Antioxidant peptides, as hydrogen donors, possibly present in SPH, could react with free radicals to convert them into more stable products and terminate the radical chain reaction [13].

DPPH radical has been widely used to evaluate the antioxidant activity of compounds to act as free radical scavengers or hydrogen donors. DPPH is a stable free radical which exhibits a maximal absorbance at $517 \mathrm{~nm}$ in ethanol solution. The free radical will be scavenged if DPPH radical encounters a proton-donating substance, such as an antioxidant. Research had demonstrated that antioxidant peptides could donate hydrogen atom to free radicals and become more stable diamagnetic molecule, giving rise to the termination of the radical chain reaction [14]. However, the efficiency in hydrogen donation of the antioxidant peptides depends on their composition, structure and concentration.

\subsection{Effect of Thermal Treated Temperature}

Thermal treatment is one of the most commonly used methods in food processing and utilization. Proteins are generally sensitive to heat, thus thermal treatment may cause the denaturation, association, and aggregation of proteins or protein hydrolysates [2]. As the temperature of heat treatment increased in the range of $65^{\circ} \mathrm{C}-100^{\circ} \mathrm{C}$, DPPH radical scavenging activity of SPH decreased from $58.15 \%$ to $44.61 \%$. There were no significant differences between different heat-treat groups (Figure 1(a)), which indicated that SPH had great resistance to thermal 
processing. Similarly, reducing power showed decline from 0.58 to 0.39 as temperature increased. The results of reducing power did not show significant differences between different groups.

High temperatures used in thermal treatment may likely increase the degradation of SPH and affect the secondary structures of SPH, which resulted in the partial loss of antioxidant activity. The results obtained in our research were consistent with the previous studies [15] [16], however, the antioxidant activity of SPH was not completely lost.

\subsection{Effect of $\mathrm{pH}$}

$\mathrm{pH}$ stability of protein hydrolysates is very important, because food protein may be encountered different $\mathrm{pH}$ during food processing, utilization and digestion. Moreover, pH stability significantly impacts the bioactivities of food proteins, especially as they pass through gastrointestinal tract.

DPPH radical scavenging activity of SPH remains relatively stable $(\mathrm{p}>0.05)$ over the range of $\mathrm{pH} 3.0$ - 7.0. (Figure 2(a)). However, DPPH radical scavenging activity significantly decreased under the alkaline condition, especially at $\mathrm{pH} 11$ (30.58\%) $(\mathrm{p}<0.05)$ (Figure 2(a)). Likewise, reducing power did not show significant differences under acidic conditions, while, it gradually decreased under alkaline conditions $(\mathrm{p}<0.05)$ (Figure $2(\mathrm{~b})$ ). The result showed that DPPH radical scavenging activity and reducing power of SPH both significantly decreased under alkaline conditions $(\mathrm{p}<0.05)$. Zhu et al., assumed that the loss of antioxidant
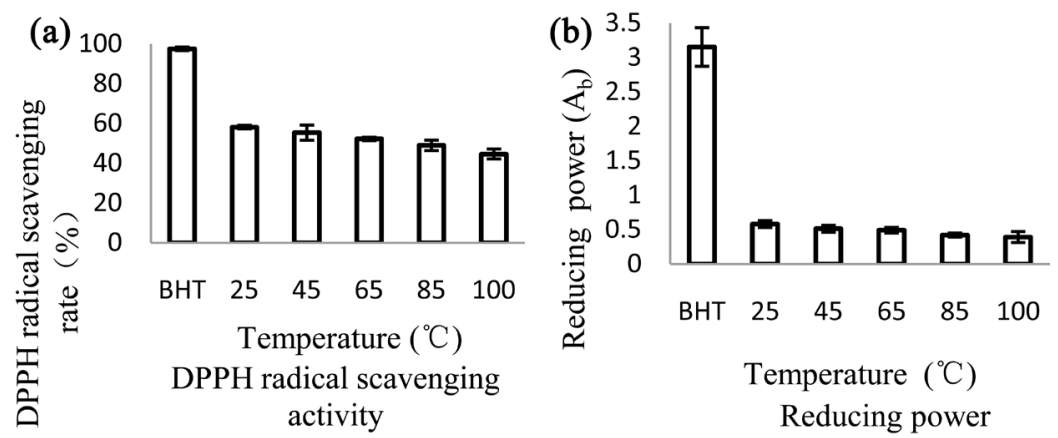

Figure 1. Effect of thermal treatment on DPPH radical scavenging activity and reducing power.
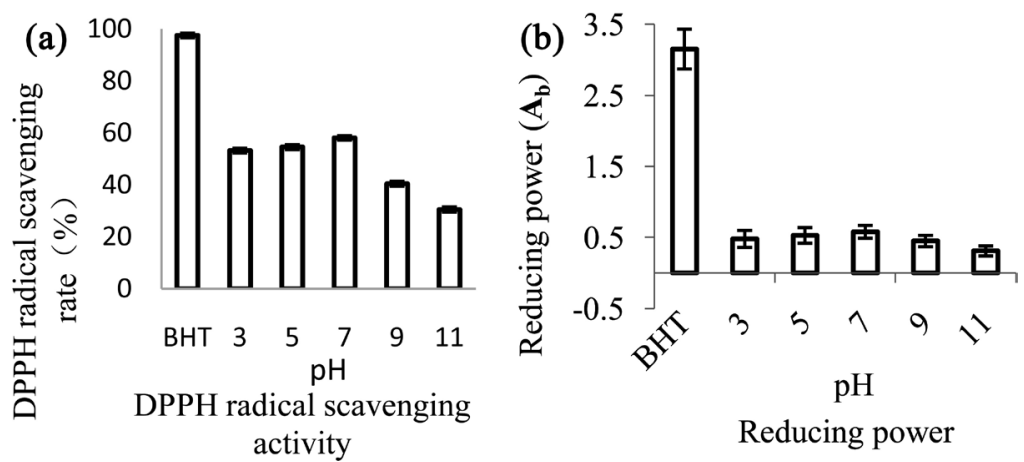

Figure 2. Effect of $\mathrm{pH}$ on DPPH radical scavenging activity and reducing power. 
activity might be caused by the racemization reaction, the deamidation reaction, and the degradation reaction of protein hydrolysates under alkaline conditions.

\subsection{Effect of Storage Time}

With the increasing of storage time, DPPH radical scavenging activity and reducing power declined from $58.15 \%$ to $53.58 \%$ and 0.58 to 0.51 , respectively (Figure 3(a), Figure 3(b)). It probably because the antioxidant groups from SPH were slightly degraded due to enzymatic and non-enzymatic oxidation which were resulted from alternation of the moisture content during storage [17].

\subsection{Effect of Sugar}

Result of effect of different sugars on DPPH radical scavenging activity of SPH at $25^{\circ} \mathrm{C}$ showed no significant differences (Figure 4(a), Figure 4(b)). However, significant differences in reducing power were found by the addition of sugars at $65^{\circ} \mathrm{C}$. D-galactose, D-Xylose, and D-Fructose might react with SPH and formed new compounds with more antioxidant activities. The results indicated that some specific sugars might react with $\mathrm{SPH}$ and altered their antioxidant stability at higher temperatures.

\subsection{Effect of Simulated Gastrointestinal Digestion}

In general, the structure and biological activity of protein hydrolysates remain
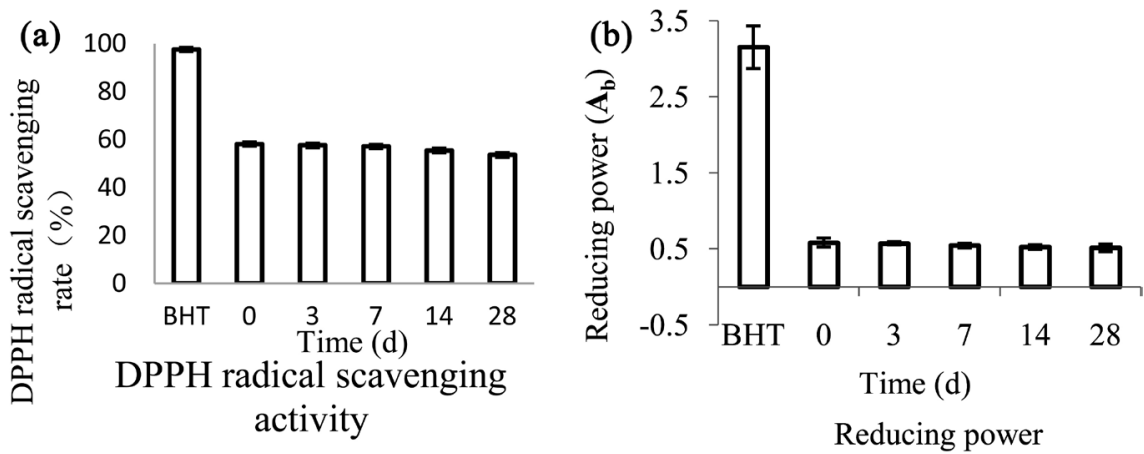

Figure 3. Effect of storage time on DPPH radical scavenging activity and reducing power.
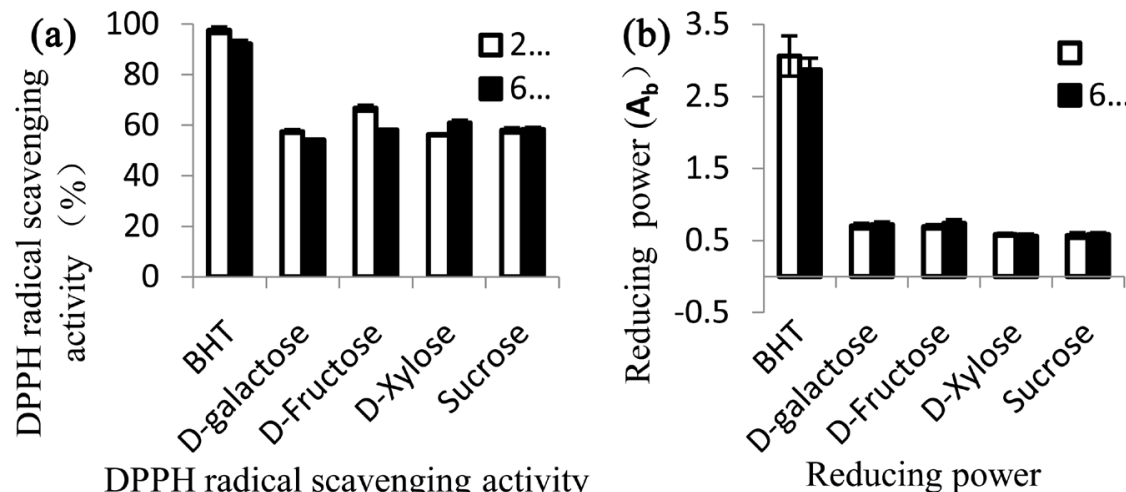

DPPH radical scavenging activity

Reducing power

Figure 4. Effect of sugar on DPPH radical scavenging activity and reducing power. 
stable at specific $\mathrm{pH}$ range, for example, under neutral $\mathrm{pH}$ conditions. The bioactivities stability of SPH in the gastrointestinal tracts were evaluated through a two-stage hydrolysis process in vitro, which simulated protein hydrolysis in the process of human digestion. Simulated gastrointestinal digestion in vitro is a simple and rapid screening experiment that is often used to assess the stability of bioactive peptides during gastrointestinal digestion [15].

As shown in Figure 5(a), after $2 \mathrm{~h}$ of digestion with pepsin, DPPH radical scavenging activity and reducing power of the samples decreased from $58.15 \%$ to $55.42 \%$ and 0.58 to 0.53 ( $\mathrm{p}>0.05$ ), respectively. Further digestion with trypsin and the complex of trypsin and chymotrypsin resulted in a continued decrease in the antioxidant activity $(\mathrm{p}<0.05)$. After $2 \mathrm{~h}$ of digestion with trypsin and chymotrypsin, DPPH radical scavenging activity and reducing power of SPH decreased from $55.42 \%$ to $48.25 \%$ and 0.53 to 0.46 ( $\mathrm{p}<0.05$ ), respectively. As a whole, the changing trend of DPPH radical scavenging activity was similar to that of reducing power during gastrointestinal digestion.

Changes in the antioxidant activity of SPH may be related to some antioxidant groups altered in the gastrointestinal tract. Enzymatic actions affected the amino acid compositions, contents, and structures of these antioxidant peptides, thereby affecting their antioxidant activity [18]. The result suggested that pepsin, trypsin, or trypsin and chymotrypsin treatment might cleave the antioxidant peptides to some degree, leading to the composition and structure alternation of these antioxidant peptides, which could cause partial loss of the antioxidative activities of SPH.

\section{Discussion}

Since protein hydrolysates are often used as functional food ingredients or food additives, the bioactivities stability during food processing, storage, utilization and digestion becomes extremely important. The compositions and structures of protein hydrolysates can be degraded, modified and restructured after they are processed, stored and react with other food components, meanwhile, their bioactivity can also be activated, degraded or inactivated during this process.

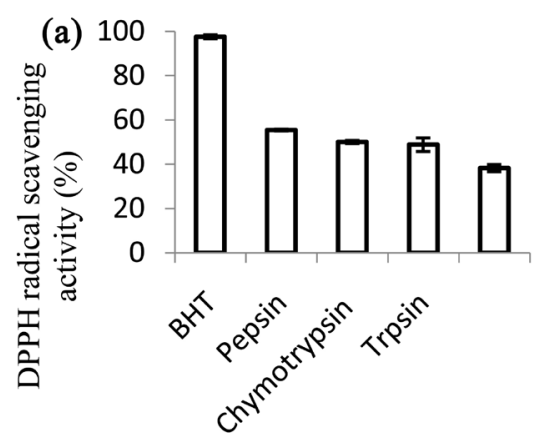

DPPH radical scavenging activity

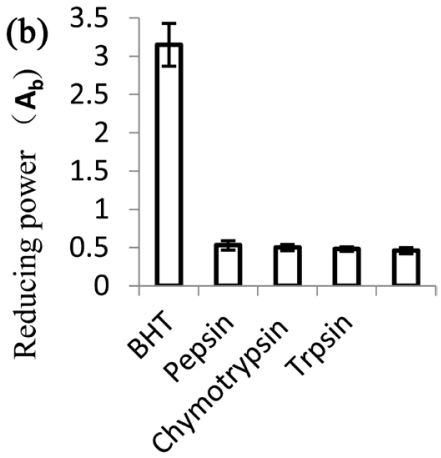

Reducing power

Figure 5. Effect of gastrointestinal digestion on DPPH radical scavenging activity and reducing power. 
Most food processing involves thermal treatments, $\mathrm{pH}$ change, addition of sugars, and so on. Singh et al. [2] found that a significant change $(\mathrm{p}<0.01)$ was observed in ABTS activity of the peptides derived from fermented soy milk at $25^{\circ} \mathrm{C}(12.67 \%), 75^{\circ} \mathrm{C}(13.21 \%)$ and $100^{\circ} \mathrm{C}(12.58 \%)$, respectively. DPPH radical scavenging activity of the above-mentioned peptides was also increased $(\mathrm{p}<$ $0.01)$ at $75^{\circ} \mathrm{C}(17.09 \%)$ and $100^{\circ} \mathrm{C}(17.52 \%)$, respectively. Jang et al. [18] reported that ATSHH from sandfish (Arctoscopus japonicus) protein partially lost its DPPH radical scavenging activity by thermal treatment at $50^{\circ} \mathrm{C}, 70^{\circ} \mathrm{C}$, and $90^{\circ} \mathrm{C}$, respectively. However, the antioxidant activity of peptides from fermented soy milk remained relatively stable from $25^{\circ} \mathrm{C}$ to $100^{\circ} \mathrm{C}$. Thermal treatment could cause irreversible changes to the secondary or tertiary structure of peptides.

Researches have demonstrated that $\mathrm{pH}$ in human stomach ranges from 2 to 5 and remains neutral in the intestine. It will take at least $2 \mathrm{~h}$ for food to pass through stomach and intestine after ingestion. Moreover, $\mathrm{pH}$ stability of the protein hydrolysates implied that they might be used in liquid food products of specific $\mathrm{pH}$ ranges and retain their bioactivities. Singh et al. [2] found that significant differences were observed in DPPH radical scavenging activity at $\mathrm{pH} 3$ $(\mathrm{p}<0.01)$ and $5(\mathrm{p}<0.05)$, and the results are similar to our research. The loss of the antioxidant activity at $\mathrm{pH} 10$ may be due to the alkaline condition which alters the amount, structure, and amino acid composition of the protein hydrolysates. In addition, the alteration of $\mathrm{pH}$ could modify the charge on protein hydrolysates, leading to the change in peptides folding, which in turn affects their antioxidant activity.

A prerequisite for peptides to exert their bioactivity in vivo is that these peptides must be able to tolerate the gastrointestinal digestion and reach specific targets, such as gastrointestinal enzymes (pepsin, trypsin and chymotrypsin), $\mathrm{pH}$ and pressure in gastrointestinal tract. Toopcham et al. [19] found the antioxidant peptides from tilapia could be resistant to the gastrointestinal digestive enzymes in vitro. The same peptides also moderately lost their antioxidant activities under acidic ( $\mathrm{pH} 2$ ) and basic ( $\mathrm{pH} 10$ and 12) conditions. Wong et al. [16] found two peptides (WAFAPA and MYPGLA) from the hydrolysate of blue-spotted stingray which could tolerate the thermal and $\mathrm{pH}$ treatment during food processing with minimum loss of their antioxidant activities. Khantaphant et al. [14] found the antioxidant activity of the muscle protein hydrolysates from the brownstripe red snapper was enhanced after consumption of flavourzyme.

In our research, reducing power of SPH was not significantly influenced by simulated gastrointestinal digestion, whereas DPPH radical scavenging activity was reduced by digestion. The decline in the content of SPH after simulated gastrointestinal digestion suggested that SPH was not susceptible to the degradation of gastrointestinal digestive enzymes. Other studies also indicated the low molecular hydrolysates were not susceptible to the effects of digestive enzymes in vitro, and they could keep the antioxidant groups and bioactivity in the gastrointestinal tract [20]. However, a thorough understanding of the relationship 
between specific composition and/or group of the hydrolysates from different protein sources and their resistant to gastrointestinal digestive enzymes still remain opaque [16].

\section{Conclusion}

The efficacy of different factors (thermal, $\mathrm{pH}$, storage time, sugars and simulated gastrointestinal digestion) in affecting the antioxidant stability of SPH was investigated. DPPH radical scavenging activity and reducing power of SPH exhibited a concentration-dependent relationship. The antioxidant activity remained relatively stable as temperature increased from $25^{\circ} \mathrm{C}$ to $100^{\circ} \mathrm{C}$. Furthermore, $\mathrm{SPH}$ was sensitive to pepsin, trypsin and chymotrypsin treatment. Results demonstrated that SPH might be used as food additives or supplements. Further studies need to be carried out to clarify the structural changes and action mode of SPH during food processing, utilization and gastrointestinal digestion.

\section{Acknowledgements}

This work was supported by Central Public-interest Scientific Institution Basal Research Fund, CAFS (No. 2019ZD1003, 2020XT0503).

\section{Conflicts of Interest}

The authors declare no conflicts of interest regarding the publication of this paper.

\section{References}

[1] Yi, Y.J., Xu, Q., Hu, X.S., Dong, P., Liao, X.J. and Zhang, Y. (2013) Shucking of Bay Scallop (Argopecten irradians) Using High Hydrostatic Pressure and Its Effect on Microbiological and Physical Quality of Adductor Muscle. Innovative Food Science \& Emerging Technologies, 18, 57-64. https://doi.org/10.1016/j.ifset.2013.02.010

[2] Singh, B.P. and Vij, S. (2018) In Vitro Stability of Bioactive Peptides Derived from Fermented Soy Milk against Heat Treatment, pH and Gastrointestinal Enzymes. LWT_Food Science and Technology, 91, 303-307. https://doi.org/10.1016/j.lwt.2018.01.066

[3] Sarmadi, B.H. and Ismail, A. (2010) Antioxidative Peptides from Food Proteins: A Review. Peptides, 31, 1949-1956. https://doi.org/10.1016/j.peptides.2010.06.020

[4] Liu, H.T., Li, Y.Y., Diao, X.P., Kong, B.H. and Liu, Q. (2018) Effect of Porcine Bone Protein Hydrolysates on the Emulsifying and Oxidative Stability of Oil-in-Water Emulsions. Colloid Surface A, 538, 757-764. https://doi.org/10.1016/j.colsurfa.2017.11.061

[5] Xie, N.N., Wang, B., Jiang, L.P., Liu, C.C. and Li, B. (2015) Hydrophobicity Exerts Different Effects on Bioavailability and Stability of Antioxidant Peptide Fractions from Casein during Simulated Gastrointestinal Digestion and Caco-2 Cell Absorption. Food Research International, 76, 518-526. https://doi.org/10.1016/j.foodres.2015.06.025

[6] Zhu, C.Z., Zhang, W.G., Kang, Z.L., Zhou, G.H. and Xu, X.L. (2014) Stability of an Antioxidant Peptide Extracted from Jinhua Ham. Meat Science, 96, 783-789. 
https://doi.org/10.1016/j.meatsci.2013.09.004

[7] Intarasirisawat, R., Benjakul, S., Visessanguan, W. and Wu, J.P. (2014) Effects of Skipjack Roe Protein Hydrolysate on Properties and Oxidative Stability of Fish Emulsion Sausage. LWT-Food Science and Technology, 58, 280-286. https://doi.org/10.1016/j.lwt.2014.02.036

[8] Marmon, S.K. and Undeland, I. (2010) Protein Isolation from Gutted Herring (Clupea harengus) Using pH-Shift Processes. Journal of Agricultural and Food Chemistry, 58, 10480-10486. https://doi.org/10.1021/jf101057q

[9] Chai, T.T., Law, Y.C., Wong, F.C. and Kim, S.K. (2015) Anti-Oxidative, Metal Chelating and Radical Scavenging Effects of Protein Hydrolysates from Blue-Spotted Stingray. Tropical Journal of Pharmaceutical Research, 14, 1349-1355. https://doi.org/10.4314/tjpr.v14i8.5

[10] Blois, M.S. (1958) Antioxidant Determinations by the Use of a Stable Free Radical. Nature, 181, 1199-1200. https://doi.org/10.1038/1811199a0

[11] Oyaizu, M. (1986) Studies on Products of Browning Reactions: Antioxidative Activities of Browning Products of Browning Reaction Prepared from Glucosamine. Japan Journal of Nutrition, 44, 307-315. https://doi.org/10.5264/eiyogakuzashi.44.307

[12] Li, R., Wang, F.Z., Chen, L., Zhu, S.N., Wu, L., Jiang, S.M., et al. (2016) A Review of Antioxidant Peptides Derived from Meat Muscle and By-Products. Antioxidants, 5, 32. https://doi.org/10.3390/antiox5030032

[13] You, L., Zhao, M., Regenstein, J.M. and Ren, J. (2010) Changes in the Antioxidant Activity of Loach (Misgurnus anguillicaudatus) Protein Hydrolysates during a Simulated Gastrointestinal Digestion. Food Chemistry, 120, 810-816. https://doi.org/10.1016/j.foodchem.2009.11.018

[14] Khantaphant, S., Benjakul, S. and Kishimura, H. (2011) Antioxidative and ACE Inhibitory Activities of Protein Hydrolysates from the Muscle of Brownstripe Red Snapper Prepared Using Pyloric Caeca and Commercial Proteases. Process Biochemistry, 46, 318-327. https://doi.org/10.1016/j.procbio.2010.09.005

[15] Wu, J. and Ding, X. (2002) Characterization of Inhibition and Stability of Soy-Protein Derived Angiotensin I-Converting Enzyme Inhibitory Peptides. Food Research International, 35, 367-375. https://doi.org/10.1016/S0963-9969(01)00131-4

[16] Wong, F.C., Xiao, J.B., Ong, M.G., Pang, M.J., Wong, S.J. and The, L.K. (2019) Identification and Characterization of Antioxidant Peptides from Hydrolysate of Blue-Spotted Stingray and Their Stability against Thermal, $\mathrm{pH}$ and Simulated Gastrointestinal Digestion Treatments. Food Chemistry, 271, 614-622. https://doi.org/10.1016/j.foodchem.2018.07.206

[17] Tripetch, B. and Borompichaichartkul, C. (2019) Effect of Packaging Materials and Storage Time on Changes of Colour, Phenolic Content, Chlorogenic Acid and Antioxidant Activity in Arabica Green Coffee Beans (Coffea arabica L. cv. Catimor). Journal of Stored Products Research, 84, Article ID: 101510. https://doi.org/10.1016/j.jspr.2019.101510

[18] Jang, H.L., Liceaga, A.M. and Yoon, K.Y. (2016) Purification, Characterisation and Stability of an Antioxidant Peptide Derived from Sandfish (Arctoscopus japunicus) Protein Hydrolysates. Journal of Functional Foods, 20, 433-442. https://doi.org/10.1016/j.jff.2015.11.020

[19] Toopcham, T., Roytrakul, S. and Yongsawatdigul, J. (2015) Characterization and Identification of Angiotensin I-Converting Enzyme (ACE) Inhibitory Peptides Derived from Tilapia Using Virgibacillus halodenitrificans SK1-3-7 Proteinases. Journal of Functional Foods, 14, 435-444. https://doi.org/10.1016/j.jff.2015.01.050 
[20] Chen, M. and Li, B. (2012) The Effect of Molecular Weights on the Survivability of Casein Derived Antioxidant Peptides after the Simulated Gastrointestinal Digestion. Innovative Food Science \& Emerging Technologies, 16, 341-348.

https://doi.org/10.1016/j.ifset.2012.07.009 